\title{
Validitas dan Praktikalitas Modul Larutan Penyangga Berbasis Inkuiri Terbimbing Dilengkapi Soal-Soal Tipe HOTS
}

\section{The Validity and Practicality of Buffer Solution Module} Based on Guided Inquiry Complemented by HOTS Type Questions

$S$ Handayani ${ }^{1}$ and Iryani ${ }^{1 *}$

${ }^{1}$ Pendidikan Kimia, Universitas Negeri Padang, Jl. Prof. Dr. Hamka, Air Tawar Barat, Padang Utara, Sumatera Barat, Indonesia 25171

*iryaniachmad62@gmail.com

\section{ARTICLE INFO}

Received 03 January 2020

Revised 21 January 2020

Published 06 February 2020

\begin{abstract}
This research development aims were to create and determine validity and practicality categories of buffer solution module based on guided inquiry equipped with HOTS type problems. This research was a Research and Development $(R \& D)$ with Plomp's development model. Instrument used was module validity and practicality questionnaire. Module was validated by 5 validators. Practicality was determined by providing a questionnaire to 2 chemistry teachers and 51 students of class XII MIPA SMAN 8 Padang. The data obtained were analysed with the Kappa Cohen formula. The result of the research obtained average kappa moment value validity $(0,90)$, average kappa moment value practicality of teacher response $(0,93)$ and the practicality of student response $(0,84)$. This result showed that the module which has been developed was very valid and practical to used in learning.
\end{abstract}

\section{KEYWORDS}

Module, Buffer Solution, Guided Inquiry, Validity, Plomp Development Model

\begin{abstract}
ABSTRAK
Penelitian pengembangan ini bertujuan untuk menghasilkan serta menentukan kategori validitas dan praktikalitas modul larutan penyangga berbasis inkuiri terbimbing dilengkapi soal-soal tipe HOTS. Jenis penelitian yang digunakan adalah Research and Development (R\&D) dengan model pengembangan Plomp. Instrumen penelitian berupa angket validitas dan praktikalitas. Modul divalidasi oleh 5 orang validator. Praktikalitas ditentukan dengan memberikan angket kepada 2 orang guru kimia dan 51 orang siswa kelas XII MIPA SMAN 8 Padang. Data yang didapatkan dianalisis dengan formula Kappa Cohen. Hasil penelitian diperoleh rata-rata nilai momen kappa $(\mathrm{k})$ validitas $(0,90)$, rata-rata nilai momen kappa $(\mathrm{k})$ praktikalitas dari respon guru $(0,93)$ dan praktikalitas dari respon siswa $(0,84)$. Hasil tersebut menunjukkan bahwa modul yang telah dikembangkan sangat valid dan praktis digunakan dalam pembelajaran.
\end{abstract}

\section{KATA KUNCI}

Modul,Larutan Penyangga, Inkuiri Terbimbing, Validitas, Model Pengembangan Plomp 


\section{PENDAHULUAN}

Kimia merupakan ilmu yang mempelajari komposisi dan struktur zat kimia serta hubungan keduanya dengan sifat zat tersebut ${ }^{[1]}$. Mata pelajaran kimia bukan saja menekankan kemampuan teoritis siswa, namun juga kemampuan pengaplikasian pada konsep-konsepnya. Salah satu materi kimia yang dipelajari di kelas XI SMA/MA pada semester genap adalah materi larutan penyangga. Siswa dapat memahami dan mengingat suatu materi lebih mudah jika dalam proses pembelajaran mereka bisa memperoleh sendiri konsep-konsep yang berkaitan dengan materi tersebut ${ }^{[2]}$.

Kurikulum 2013 revisi 2018 menekankan pembelajaran dengan berpusat pada siswa (student centered). Dalam proses pembelajarannya, siswa dituntut untuk mampu belajar secara aktif dan mandiri untuk mencari dan menemukan pengetahuannya sendiri, serta belajar dengan pola berpikir kritis ${ }^{[3]}$. Kurikulum 2013 juga menuntut pelaksanaan pembelajaran dengan menggunakan pendekatan saintifik yang dapat membantu siswa belajar lebih aktif, baik dengan pola belajar sendiri maupun kelompok.

Pelaksanaan pembelajaran menggunakan pendekatan saintifik salah satunya dapat diterapkan dengan model pembelajaran inkuiri terbimbing. Model inkuiri terbimbing memiliki 5 tahapan pembelajaran, yang terdiri dari tahap orientasi, tahap eksplorasi, tahap pembentukan konsep, tahap aplikasi, dan tahap penutup ${ }^{[4]}$.

Model pembelajaran inkuiri terbimbing menekankan pembelajaran melalui keterlibatan, motivasi, dan belajar menyelesaikan permasalahan sesuai dengan tujuan lembaga pendidikan untuk membimbing siswa berpikir dan belajar melalui penyelidikan $^{[5]}$. Model pembelajaran inkuiri terbimbing dapat diaplikasikan ke dalam bentuk bahan ajar yang mampu membantu siswa dalam memperoleh serta membangun konsep atau pengetahuannya sendiri melalui tahapan inkuiri terbimbing. Bahan ajar ini disebut sebagai bahan ajar berbasis inkuiri terbimbing. Salah satu bahan ajar yang dapat digunakan adalah modul. Pembelajaran dengan menggunakan modul membuat siswa mampu menyesuaikan kecepatan belajarnya berdasarkan kemampuan mereka masing-masing, serta dapat mengukur penguasaan mereka terhadap materi yang sedang dipelajari ${ }^{[6]}$.

Kementerian pendidikan dan kebudayaan mulai mengembangkan pembelajaran berorientasi HOTS (Higher Order Thinking Skills) sebagai upaya untuk meningkatkan kualitas pembelajaran dan kualitas lulusan ${ }^{[7]}$. Salah satu upaya yang dapat dilakukan adalah melengkapi soal-soal yang terdapat pada bahan ajar dengan soal-soal tipe HOTS yang berada pada ranah kognitif C4-C6 taksonomi bloom revisi. Penilaian hasil belajar dengan soal-soal tipe HOTS diharapkan mampu membantu siswa untuk menerapkan kemampuan berpikir tingkat tinggi yang dapat mendorong siswa untuk berpikir secara luas dan mendalam terhadap materi pembelajaran ${ }^{[8]}$.

Pengembangan bahan ajar berbasis inkuiri terbimbing pada materi larutan penyangga sebelumnya telah dilakukan oleh Ifelicia (2017). Ifelicia telah menghasilkan bahan ajar pada materi larutan penyangga dilengkapi multipel representasi yang telah valid dan praktis. Namun, bahan ajar yang dihasilkan belum dilengkapi dengan soal-soal tipe HOTS (Higher Order Thinking Skills) baik pada lembar kerja maupun pada lembar evaluasi.

Hasil yang diperoleh dari wawancara guru kimia serta analisis angket siswa di SMAN 12 Padang dan SMAN 8 Padang menunjukkan bahwa umumnya bahan ajar tentang larutan penyangga yang terdapat di sekolah tersebut berupa buku paket dan LKS/LKPD, sedangkan bahan ajar berupa modul belum tersedia di sekolah tersebut. Selain itu, bahan ajar pada materi larutan penyangga yang digunakan oleh guru di sekolah tersebut belum dilengkapi soal-soal tipe HOTS baik pada lembar kerja maupun pada lembar evaluasinya, sehingga belum mampu melatih kemampuan berpikir tingkat tinggi siswa.

Penggunaan bahan ajar kimia berbasis inkuiri terbimbing mampu memberikan pengaruh yang positif terhadap hasil belajar siswa ${ }^{[9]}$. Selain itu, penyajian bahan ajar dengan soal-soal tipe HOTS dapat membantu siswa untuk memperoleh pemahaman konseptual secara mendalam dan melatih kemampuan berpikir tingkat tinggi siswa untuk memecahkan permasalahan yang baru dalam situasi berbeda ${ }^{[10]}$. Oleh karena itu, pada penelitian ini dilakukan pengembangan modul larutan penyangga berbasis inkuiri terbimbing dilengkapi soal-soal tipe HOTS serta menentukan kategori validitas dan praktikalitas terhadap modul yang telah dikembangkan.

\section{METODE}

Jenis penelitian ini adalah penelitian dan pengembangan atau Research and Development (R\&D) dengan model pengembangan Plomp. Model pengembangan Plomp terdiri atas tiga tahapan yaitu: tahap penelitian awal (preliminary research), tahap pembentukan prototipe (prototyping phase), dan tahap penilaian (assessment phase) ${ }^{[11]}$. Subjek penelitian terdiri dari dosen kimia FMIPA UNP, guru kimia dan siswa kelas XII MIPA SMAN 8 Padang, sedangkan objek penelitian berupa modul larutan penyangga berbasis inkuiri terbimbing dilengkapi soal-soal tipe HOTS.

Pada tahap penelitian awal (preliminary research), dilakukan 4 kegiatan yaitu: (1) analisis kebutuhan dengan mewawancarai guru kimia SMA dan memberikan angket kepada siswa; (2) analisis konteks dengan mengidentifikasi, merinci, serta menyusun materi-materi pokok pada larutan penyangga yang harus dikuasai siswa yang berupa analisis terhadap Kompetensi Dasar (KD) berdasarkan kurikulum 2013 revisi 2018; (3) studi literatur dengan mencari serta memahami sumber atau referensi yang berkaitan; 
(4) pengembangan kerangka konseptual dilakukan dengan cara menganalisis, mengidentifikasi, merinci, serta menyusun konsep-konsep pokok pada materi larutan penyangga.

Pada tahap pembentukan prototipe (prototyping phase), dilakukan perancangan produk berupa modul yang bertujuan untuk meningkatkan dan menyempurnakan produk yang dihasilkan. Tahap pembentukan prototipe terdiri dari prototipe I sampai dengan prototipe IV. Pada prototipe I dilakukan perancangan modul larutan penyangga berbasis inkuiri terbimbing berdasarkan KD, IPK, dan tujuan pembelajaran berdasarkan Kurikulum 2013 revisi 2018. Pada prototipe II dilakukan evaluasi diri sendiri (self evaluation) terhadap prototipe I yang telah dihasilkan. Pada prototipe III dilakukan uji coba satu satu (one to one evaluation) dan penilaian ahli (expert review) terhadap prototipe II yang telah dihasilkan. Pada prototipe IV dilakukan evaluasi terhadap prototipe III dengan uji coba kelompok kecil (small group).

Pada tahap penilaian (assessment phase), dilakukan evaluasi semi-sumatif yang berupa uji lapangan (field test). Hal tersebut bertujuan untuk menghasilkan kualitas produk yang lebih baik.

Data yang didapatkan berupa data kuantitatif yang digunakan untuk menentukan kategori validitas dan praktikalitas dari modul yang telah dikembangkan. Instrumen penelitian berupa angket lembar validasi dan praktikalitas modul. Data yang didapatkan dari validator dianalisis dengan formula Kappa Cohen seperti pada persamaan berikut.

$$
\text { momen kappa }(k)=\frac{\rho_{0}-\rho_{e}}{1-\rho_{e}}
$$

Keterangan:

$k=$ nilai dari momen kappa

$\rho_{e}=$ proporsi yang terealisasi

$\rho_{0}=$ proporsi yang tidak terealisasi

Tabel 1. Kategori keputusan berdasarkan momen Kappa $^{[12]}$.

\begin{tabular}{c|c} 
Interval & Kategori \\
\hline $0,81-1,00$ & Sangat tinggi \\
\hline $0,61-0,80$ & Tinggi \\
\hline $0,41-0,60$ & Sedang \\
\hline $0,21-0,40$ & Rendah \\
\hline $0,01-0,20$ & Sangat rendah \\
\hline$<0,00$ & Tidak valid
\end{tabular}

\section{HASIL DAN DISKUSI}

\subsection{Tahap Penelitian Awal (Preliminary Research)}

\subsubsection{Analisis Kebutuhan}

Hasil analisis kebutuhan didapatkan setelah melakukan wawancara dengan 4 orang guru kimia, yaitu: 2 orang guru kimia SMAN 8 Padang dan 2 orang guru kimia SMAN 12 Padang, serta memberikan angket kepada siswa kelas XII MIPA SMAN 8 Padang dan siswa kelas XII MIPA SMAN 12 Padang.

Kegiatan analisis kebutuhan melalui wawancara guru dan penyebaran angket kepada siswa menunjukkan hasil bahwa bahan ajar guru pada materi larutan penyangga di kedua sekolah tersebut umumnya berupa buku paket dan LKS/LKPD dengan persentase penggunaannya sebesar 25\% di SMAN 8 Padang dan 26\% di SMAN 12 Padang. Namun, persentase penggunaan modul di sekolah tersebut hanya $15 \%$ di SMAN 8 Padang dan 11\% di SMAN 12 Padang. Bahan ajar yang digunakan tersebut belum mampu membantu siswa belajar secara aktif dan mandiri untuk menemukan konsep. Hal ini dibuktikan dengan 27\% siswa kelas XII MIPA di SMAN 8 Padang dan 23\% siswa kelas XII MIPA di SMAN 12 Padang yang hanya mampu belajar secara aktif dan mandiri dengan bahan ajar yang sudah tersedia. Selain itu, 63\% siswa kelas XII MIPA SMAN 8 Padang dan 57\% siswa kelas XII MIPA SMAN 12 Padang masih cenderung menghafal pada materi larutan penyangga. Hal ini dikarenakan dalam proses pembelajaran guru masih cenderung memberikan rumus-rumus, sehingga guru masih menjadi pusat pembelajaran.

\subsubsection{Analisis Konteks}

Analisis konteks yang dilakukan berupa analisis silabus kurikulum 2013 yaitu analisis terhadap KD yangdiuraikan menjadi IPK dan tujuan pembelajaran. Kompetensi dasar (KD) untuk materi larutan penyangga sesuai kurikulum 2013 revisi adalah $\mathrm{KD}$ 3.12. Menjelaskan prinsip kerja, perhitungan $\mathrm{pH}$, dan peran larutan penyangga dalam tubuh makhluk hidup dan KD 4.12 Membuat larutan penyangga dengan $\mathrm{pH}$ tertentu. Berdasarkan kompetensi dasar tersebut, dapat dirumuskan indikator pencapaian kompetensi (IPK) yaitu, (1) menjelaskan pengertian larutan penyangga; (2) membandingkan sifat larutan penyangga dan bukan larutan penyangga; (3) menentukan komponen larutan penyangga; (4) menjelaskan prinsip kerja larutan penyangga; (5) menganalisis cara pembuatan larutan penyangga secara langsung dan secara tidak langsung; (6) menghitung $\mathrm{pH}$ larutan penyangga; (7) menjelaskan peranan larutan penyangga dalam tubuh makhluk hidup dan industri; dan (8) melakukan percobaan untuk membuat larutan penyangga dengan $\mathrm{pH}$ tertentu. 


\subsubsection{Studi Literatur}

Hasil yang diperoleh dari kegiatan studi literatur adalah (1) Komponen modul dirujuk dari Suryosubroto. (2) Isi materi pada modul terkait dengan materi larutan penyangga dirujuk dari bukubuku perguruan tinggi serta buku kimia sekolah. (3) Materi terkait model pembelajaran inkuiri terbimbing dan keterampilan berpikir tingkat tinggi dirujuk dari buku-buku, jurnal-jurnal, maupun internet.

\subsubsection{Pengembangan Kerangka Konseptual}

Hasil dari kegiatan pengembangan kerangka konseptual didapatkan melalui analisis konsep materi larutan penyangga. Konsep-konsep utama materi larutan penyangga yang harus dikuasai siswa selama proses pembelajaran antara lain: kesetimbangan ion dalam larutan, larutan penyangga, $\mathrm{pH}$ atau derajat keasaman, larutan penyangga asam, larutan penyangga basa, kapasitas buffer, sistem penyangga karbonat, sistem penyangga fosfat, sistem penyangga asam amino, asam lemah, basa konjugasi, asam konjugasi, dan basa lemah.

\subsection{Tahap Pembentukan Prototipe (Prototyping Phase)}

Tahap ini menghasilkan 4 prototipe, dimana masing-masing prototipe tersebut dilakukan evaluasi formatif sehingga didapatkan prototipe final atau produk akhir.

\subsubsection{Prototipe I}

Prototipe I dirancang berdasarkan hasil yang telah diperoleh dari tahap penelitian awal. Prototipe I menghasilkan modul larutan penyangga berbasis inkuiri terbimbing yang memiliki beberapa komponen yaitu cover, daftar isi, daftar gambar, peta konsep, petunjuk penggunaan modul, kompetensi inti, kompetensi dasar, indikator pencapaian kompetensi, tujuan pembelajaran, lembar kegiatan, lembar kerja, lembar evaluasi, lembar tes, kunci lembar kerja, kunci lembar evaluasi, kunci lembar tes, dan kepustakaan. Modul yang dihasilkan pada prototipe I mengikuti tahapan pembelajaran inkuiri terbimbing menurut Hanson.

Tahapan orientasi merupakan tahapan dimana mempersiapkan siswa untuk belajar. Tahap orientasi memuat indikator pencapaian kompetensi, materi pendukung dan motivasi, serta gambaran materi yang akan dipelajari siswa.

Tahapan eksplorasi dan pembentukan konsep merupakan tahapan dimana siswa melakukan pengamatan atau analisis terhadap model yang diberikan agar mereka dapat menemukan konsep dengan menjawab pertanyaan kunci yang diberikan. Model yang disajikan dapat berupa gambar, tabel, satu atau lebih persamaan, serta eksperimen laboratorium. Keterampilan berpikir yang dapat dilatih pada tahapan ini diantaranya adalah keterampilan mengidentifikasi hal yang relevan berdasarkan model dan percobaan, menginterpretasikan pertanyaan kunci, menjawab pertanyaan kunci berdasarkan model yang diberikan, dan melaporkan dalam bentuk tabel pengamatan berdasarkan hasil percobaan yang dilakukan.

Tahapan aplikasi merupakan tahap penerapan konsep yang telah didapatkan siswa melalui latihan-latihan dan soal-soal. Tahapan aplikasi pada modul diintegrasikan dengan komponen modul yang berupa lembaran kerja. Soal-soal aplikasi yang diberikan pada modul berupa soal yang berbentuk esai atau uraian. Beberapa soal yang diberikan merupakan soal-soal tipe HOTS dengan ranah kognitif $\mathrm{C} 4$ taksonomi bloom revisi yang dapat membantu melatih kemampuan berpikir tingkat tinggi siswa. Keterampilan berpikir yang dapat dilatih pada tahapan ini adalah keterampilan menerapkan konsep dan prinsip/rumus yang telah diperoleh, dan menjawab pertanyaan pada soal-soal latihan.

Tahapan penutup merupakan tahap dimana siswa membuat kesimpulan berdasarkan konsep yang telah ditemukan. Keterampilan berpikir yang dapat dilatih pada tahap ini adalah keterampilan menarik kesimpulan berdasarkan hasil penyelidikan.

\subsubsection{Prototipe II}

Prototipe II diperoleh dengan melakukan evaluasi diri sendiri terhadap prototipe I. Hasil tersebut dilihat berdasarkan kelengkapan komponen-komponen pada modul berbasis inkuiri terbimbing dengan sistem checklist serta kesalahankesalahan yang terdapat pada modul. Berdasarkan evaluasi diri sendiri, diperoleh hasil bahwa prototipe I membutuhkan revisi terhadap kelengkapan komponen modul yang harus ada pada modul tersebut. Komponen modul yang ditambahkan setelah melakukan evaluasi diri sendiri adalah kunci jawaban lembaran kerja serta kunci jawaban lembaran evaluasi.

\subsubsection{Prototipe III}

Prototipe III diperoleh dengan melakukan evaluasi formatif terhadap prototipe II yang berupa uji coba satu satu dan penilaian ahli. Uji tersebut dilakukan dengan mewawancarai 3 orang siswa kelas XII MIPA SMAN 8 Padang yang memiliki kemampuan tinggi, sedang, dan rendah.

Pada uji coba satu satu terhadap prototipe II, diperoleh hasil bahwa modul sudah memiliki tampilan menarik dan tidak membosankan seperti cover dan desain warna, sehingga dapat memunculkan keinginan siswa untuk membacanya. Huruf yang digunakan pada modul sudah tepat dan jelas terbaca. Penyajian materi larutan penyangga pada modul sudah terstruktur dan menggunakan bahasa yang mudah dipahami. Tahapan pembelajaran inkuiri terbimbing pada modul telah jelas serta mudah dipahami. Model-model yang diberikan pada modul dapat menuntun siswa untuk menemukan konsep dengan menjawab pertanyaan kunci yang diberikan serta mampu melatih berpikir kritis siswa.

Penilaian ahli bertujuan untuk mengetahui nilai validitas dari modul yang telah dihasilkan. 
Validasi terhadap prototipe II dilakukan oleh 5 orang validator, yaitu 2 orang dosen kimia FMIPA UNP dan 3 orang guru kimia SMAN 8 Padang. Data yang didapatkan dari validator diolah dengan formula Kappa Cohen, sehingga diperoleh momen kappa ( $k$ ) yang dapat menentukan kategori kevalidan dari modul yang telah dihasilkan. Hasil analisis data validitas modul berdasarkan penilaian validator dapat dilihat pada Tabel 2.

Tabel 2. Rerata nilai momen Kappa $(k)$ untuk validitas modul berdasarkan penilaian 5 orang validator

\begin{tabular}{c|c|c}
$\begin{array}{c}\text { Aspek yang } \\
\text { Dinilai }\end{array}$ & $\mathbf{k}$ & $\begin{array}{c}\text { Kategori } \\
\text { Kevalidan }\end{array}$ \\
\hline Kelayakan Isi & 0,90 & Sangat tinggi \\
\hline $\begin{array}{c}\text { Kelayakan } \\
\text { Konstruk }\end{array}$ & 0,94 & Sangat tinggi \\
\hline $\begin{array}{c}\text { Komponen } \\
\text { Kebahasaan }\end{array}$ & 0,88 & Sangat tinggi \\
\hline $\begin{array}{c}\text { Komponen } \\
\text { Kegrafisan }\end{array}$ & 0,89 & Sangat tinggi \\
\hline k validitas & $\mathbf{0 , 9 0}$ & Sangat Tinggi
\end{tabular}

Penilaian validitas berdasarkan kelayakan isi dari hasil analisis data sesuai dengan Tabel 2, momen kappa yang diperoleh dari aspek kelayakan isi adalah 0,90 yang memiliki kategori kevalidan sangat tinggi. Hasil tersebut berarti bahwa modul yang dihasilkan sudah sesuai dengan kurikulum yang ditetapkan dan rasional teoritik yang kuat. Hal tersebut dilihat dari kesesuaian isi modul dengan KD yang telah ditetapkan pada kurikulum 2013 revisi 2018; kesesuaian IPK dan tujuan pembelajaran dengan kompetensi dasar; kesesuaian motivasi dan apersepsi, materi prasyarat, model, dan latihan yang diberikan dengan IPK atau materi yang diajarkan; serta kesesuaian tahapan pembelajaran pada lembar kegiatan dengan model inkuiri terbimbing menurut Hanson.

Penilaian validitas berdasarkan kelayakan konstruk (komponen penyajian) menunjukkan konsistensi internal antar komponen-komponen yang ada pada modul. Berdasarkan hasil analisis data sesuai dengan Tabel 2, momen kappa yang diperoleh dari aspek kelayakan konstruk (komponen isi) adalah 0,94 yang memiliki kategori kevalidan sangat tinggi. Hasil tersebut berarti bahwa komponen-komponen modul larutan penyangga berbasis inkuiri terbimbing telah tersusun secara sistematis berdasarkan komponen modul menurut Suryosubroto. Penyajian modul yang terdiri dari aktivitas kelas dan aktivitas laboratorium telah sesuai dengan tahapan pembelajaran inkuiri terbimbing menurut Hanson ${ }^{[4]}$ dan The College Board. Selain itu, pertanyaan kunci yang disajikan pada modul telah tersusun secara sistematis dari pertanyaan kognitif yang rendah sampai kognitif tinggi sehingga dapat menuntun siswa untuk menemukan konsep dengan mengeksplorasi model yang telah disajikan.

Penilaian kebahasaan merupakan penilaian kevalidan terhadap penggunaan bahasa pada modul yang telah dikembangkan. Berdasarkan hasil analisis data sesuai dengan Tabel 2, momen kappa yang diperoleh dari aspek komponen kebahasaan adalah 0,88 yang memiliki kategori kevalidan sangat tinggi. Hasil tersebut berarti bahwa bahasa yang digunakan pada modul sudah sesuai dengan kaidah Bahasa Indonesia yang baik dan benar, jelas dan mudah dipahami, serta konsisten dalam menggunakan simbol atau lambang. Hal tersebut telah sesuai dengan komponen kebahasaan dari suatu bahan ajar yang baik menurut Depdiknas (2008) ${ }^{[13]}$.

Hasil analisis data validitas berdasarkan komponen kegrafisan sesuai dengan Tabel 2, diperoleh nilai momen kappa 0,89 dengan kategori kevalidan sangat tinggi. Hasil tersebut berarti bahwa tampilan modul secara keseluruhan dinilai telah menarik, baik dari segi kejelasan gambar dan model, jenis dan ukuran huruf, tata letak (layout), penggunaan warna pada modul maupun desain pada cover modul. Hal tersebut telah sesuai dengan komponen kegrafisan dari suatu bahan ajar yang baik menurut Depdiknas (2008) ${ }^{[13]}$.

Hasil analisis penilaian validitas berdasarkan keempat aspek yang dinilai pada Tabel 2 menunjukkan bahwa modul yang telah dihasilkan memiliki kategori kevalidan sangat tinggi. Hal tersebut dibuktikan dari rata-rata momen kappa berdasarkan keempat aspek tersebut memperoleh nilai 0,90 .

\subsubsection{Prototipe $I V$}

Prototipe IV diperoleh dengan melakukan evaluasi formatif yang berupa uji coba kelompok kecil (small group evaluation) terhadap prototipe III yang telah dihasilkan. Uji coba kelompok kecil dilakukan kepada 6 orang siswa kelas XII MIPA di SMAN 8 Padang dengan kemampuan berbeda yaitu tinggi, sedang, dan rendah. Hasil analisis data praktikalitas modul berdasarkan angket respon siswa pada uji coba kelompok kecil dapat dilihat pada Tabel 3.

Tabel 3. Rerata nilai momen Kappa ( $k$ ) untuk praktikalitas modul berdasarkan angket respon siswa pada uji coba kelompok kecil

\begin{tabular}{c|c|c}
$\begin{array}{c}\text { Aspek yang } \\
\text { Dinilai }\end{array}$ & $\mathbf{k}$ & $\begin{array}{c}\text { Kategori } \\
\text { Kepraktisan }\end{array}$ \\
\hline $\begin{array}{c}\text { Kemudahan } \\
\text { Penggunaan }\end{array}$ & 0,85 & Sangat tinggi \\
\hline $\begin{array}{c}\text { Efisiensi Waktu } \\
\text { Pembelajaran }\end{array}$ & 0,80 & Tinggi \\
\hline Manfaat & 0,77 & Tinggi \\
\hline Rata-rata k & $\mathbf{0 , 8 1}$ & $\begin{array}{c}\text { Sangat } \\
\text { Tinggi }\end{array}$
\end{tabular}


Berdasarkan Tabel 3, rata-rata momen kappa praktikalitas dari angket respon siswa melalui uji coba kelompok kecil diperoleh nilai 0,81 dengan kategori kepraktisan sangat tinggi. Hasil tersebut menunjukkan bahwa modul dalam bentuk prototipe III yang telah dihasilkan sudah praktis untuk digunakan, baik dari aspek kemudahan penggunaan, efisiensi waktu pembelajaran, maupun manfaat.

\subsection{Tahap Penilaian (Assessment Phase)}

Tahap ini dilakukan dengan evaluasi semisumatif yang berupa uji lapangan (field test) terhadap prototipe IV yang telah dihasilkan. Hasil uji lapangan ini diperoleh melalui penilaian berdasarkan angket respon guru dan angket respon siswa.

\subsubsection{Praktikalitas Berdasarkan Angket Respon Guru}

Penilaian praktikalitas berdasarkan angket respon guru diperoleh dari 2 orang guru kimia SMAN 8 Padang. Hasil analisis data penilaian praktikalitas modul berdasarkan angket respon guru dapat dilihat pada Tabel 4.

Tabel 4. Rerata nilai momen Kappa ( $k$ ) untuk praktikalitas modul berdasarkan angket respon guru pada uji lapangan

\begin{tabular}{c|c|c}
$\begin{array}{c}\text { Aspek yang } \\
\text { Dinilai }\end{array}$ & $\mathbf{k}$ & $\begin{array}{c}\text { Kategori } \\
\text { Kepraktisan }\end{array}$ \\
\hline $\begin{array}{c}\text { Kemudahan } \\
\text { Penggunaan }\end{array}$ & 0,98 & Sangat tinggi \\
\hline $\begin{array}{c}\text { Efisiensi Waktu } \\
\text { Pembelajaran }\end{array}$ & 0,89 & Sangat tinggi \\
\hline Manfaat & 0,92 & Sangat tinggi \\
\hline Rata-rata k & $\mathbf{0 , 9 3}$ & $\begin{array}{c}\text { Sangat } \\
\text { Tinggi }\end{array}$
\end{tabular}

Hasil analisis data praktikalitas berdasarkan angket respon guru sesuai dengan Tabel 4 diperoleh nilai rata-rata momen kappa sebesar 0,93. Hasil tersebut menunjukkan bahwa modul yang telah dikembangkan memiliki kategori kepraktisan yang sangat tinggi.

\subsubsection{Praktikalitas Berdasarkan Angket Respon Siswa}

Penilaian praktikalitas berdasarkan angket respon siswa diperoleh dari 45 orang siswa kelas XII MIPA SMAN 8 Padang. Hasil analisis data penilaian praktikalitas berdasarkan angket respon siswa dapat dilihat pada Tabel 5 .

Hasil analisis data praktikalitas berdasarkan angket respon siswa sesuai dengan Tabel 5 diperoleh nilai rata-rata momen kappa sebesar 0,84 . Hasil tersebut menunjukkan bahwa modul yang telah dikembangkan memiliki kategori kepraktisan yang sangat tinggi.

Berdasarkan hasil penilaian praktikalitas yang diperoleh dari angket respon guru dan angket respon siswa di atas, modul larutan penyangga berbasis inkuiri terbimbing dilengkapi soal-soal tipe HOTS yang dihasilkan dinilai telah praktis sesuai dengan
3 aspek yang dinilai. Berdasarkan aspek kemudahan penggunaan, modul yang dihasilkan mudah dipahami baik dari segi petunjuk, materi, bahasa, pertanyaan kunci, maupun tahapan pembelajaran inkuiri terbimbing yang digunakan. Hal ini sesuai dengan pendapat Majid (2012) yang menyatakan bahwa suatu modul akan bermakna jika siswa dapat dengan mudah menggunakannya ${ }^{[14]}$.

Tabel 5. Rerata nilai momen Kappa ( $k$ ) untuk praktikalitas modul berdasarkan angket respon siswa pada uji lapangan

\begin{tabular}{c|c|c}
$\begin{array}{c}\text { Aspek yang } \\
\text { Dinilai }\end{array}$ & $\mathbf{k}$ & $\begin{array}{c}\text { Kategori } \\
\text { Kepraktisan }\end{array}$ \\
\hline $\begin{array}{c}\text { Kemudahan } \\
\text { Penggunaan }\end{array}$ & 0,86 & Sangat tinggi \\
\hline $\begin{array}{c}\text { Efisiensi Waktu } \\
\text { Pembelajaran }\end{array}$ & 0,81 & Sangat tinggi \\
\hline Manfaat & 0,85 & Sangat tinggi \\
\hline Rata-rata k & $\mathbf{0 , 8 4}$ & $\begin{array}{c}\text { Sangat } \\
\text { Tinggi }\end{array}$
\end{tabular}

Berdasarkan aspek efisiensi waktu pembelajaran, modul yang dihasilkan telah efisien dan dapat membantu siswa untuk belajar dengan kecepatannya masing-masing. Penggunaan modul dalam pembelajaran memungkinkan siswa yang memiliki kecepatan tinggi dalam belajar akan lebih cepat untuk menyelesaikan satu atau lebih KD dibandingkan dengan siswa lainnya ${ }^{[14]}$.

Berdasarkan aspek manfaat, tahapan pembelajaran inkuiri terbimbing yang termuat dalam modul dapat memudahkan siswa dalam mempelajari materi, lembar kerja dapat meningkatkan pemahaman siswa terhadap materi, lembar evaluasi dapat mengukur keberhasilan siswa terhadap materi, kunci jawaban dapat membantu siswa mengukur kemampuannya sendiri. Selain itu, modul yang dihasilkan dapat membantu siswa untuk belajar secara mandiri dan dapat meningkatkan minat siswa untuk belajar. Hal ini dapat mendukung peranan guru sebagai fasilitator serta sesuai dengan fungsi modul sebagai bahan ajar mandiri, pengganti fungsi pendidik, sebagai alat evaluasi, dan sebagai bahan rujukan bagi siswa ${ }^{[15]}$.

Hasil analisis jawaban siswa pada modul larutan penyangga berbasis inkuiri terbimbing dilengkapi soal-soal tipe HOTS diperoleh rata-rata nilai siswa sebesar 81,3. Hasil tersebut membuktikan bahwa terdapat hubungan yang relevan antara jawaban siswa pada modul dengan penilaian praktikalitas berdasarkan angket respon siswa dengan kategori baik. Hal ini dikarenakan nilai yang didapatkan telah mencapai KKM untuk mata pelajaran kimia kelas XI di sekolah tersebut yaitu 81 .

Hasil analisis jawaban siswa di atas menunjukkan bahwa penggunaan modul larutan penyangga berbasis inkuiri terbimbing yang dilengkapi soal-soal tipe HOTS dapat menuntun 
siswa untuk menemukan konsep, memahami konsep, serta mengaplikasikan konsep dalam bentuk soal latihan. Hal ini berarti bahwa penerapan siklus pembelajaran inkuiri terbimbing pada modul dapat melatih keterampilan berpikir kritis siswa yang dibuktikan dengan siswa dapat menjawab pertanyaan-pertanyaan kunci dengan mengeksplorasi model yang telah disajikan. Pertanyaan-pertanyaan kunci inilah yang menentukan keberhasilan modul dalam menuntun siswa untuk menemukan konsep karena merupakan inti dari kegiatan inkuiri terbimbing ${ }^{[4]}$.

Modul yang dihasilkan juga dilengkapi soalsoal tipe HOTS baik pada lembar kerja maupun pada lembar evaluasi. Soal-soal tipe HOTS ini merupakan soal-soal yang dibatasi pada ranah kognitif C4 berdasarkan taksonomi Bloom revisi. Berdasarkan analisis jawaban siswa terhadap soal-soal tipe LOTS dan HOTS yang terdapat pada modul, diperoleh rata-rata keberhasilan siswa menjawab soal-soal tipe LOTS pada modul sebesar $81,4 \%$ untuk lembar kerja dan 81,9\% untuk lembar evaluasi. Sedangkan rata-rata keberhasilan siswa yang menjawab soalsoal tipe HOTS pada modul diperoleh sebesar $69,2 \%$ untuk lembar kerja dan $63,1 \%$ untuk lembar evaluasi.

Hasil analisis jawaban di atas menunjukkan bahwa soal-soal tipe HOTS pada modul dapat melatih kemampuan berpikir tingkat tinggi siswa, dimana kemampuan berpikir ini tidak hanya sekadar mengingat (recall), menyatakan kembali (restate), atau merujuk tanpa melakukan pengolahan (recite). Hal ini dibuktikan dengan kemampuan siswa untuk menjawab soal-soal tipe HOTS yang diberikan pada modul sudah cukup baik.

\section{SIMPULAN}

Penelitian pengembangan yang dilakukan telah menghasilkan modul larutan penyangga berbasis inkuiri terbimbing dilengkapi soal-soal tipe HOTS melalui tahapan pengembangan Plomp. Modul yang telah dikembangkan memiliki nilai momen kappa validitas 0,90. Modul yang telah dikembangkan memiliki nilai momen kappa praktikalitas dari respon guru 0,93 dan dari respon siswa 0,84. Hasil tersebut menunjukkan bahwa modul yang telah dikembangkan sangat valid dan praktis untuk digunakan dalam pembelajaran.

\section{REFERENSI}

1. Syukri S. Kimia Dasar. Bandung: ITB; 1999.

2. Mirjannah M, dkk. Peningkatan Aktivitas dan Hasil Belajar Siswa Melalui Penerapan Model Learning Cycle 7E (LC 7E) pada pembelajaran Biologi Kelas X IPA 4 SMA Negeri 1 Bringin Tahun Pelajaran 2016/2017. I Varidika 2017;29(1):18-27.

3. RI P. Perubahan Atas Peraturan Menteri Pendidikan Dan Kebudayaan Nomor 59 Tahun 2014 Tentang Kurikulum 2013 Sekolah Menengah Atas/Madrasah Aliyah. 2018.

4. Hanson DM. Designing Process-Oriented
Guided-Inquiry Activities. Pacific Crest 2005;(2nd edition).

5. Putra MIS, Widodo W, Jatmiko B. The Development of Guided Inquiry Sciens Learning Materials to Improve Science Literacy Skill of Prospective MI Teachers. I Pendidik IPA Indones 2016;5(1):83-93.

6. Septiani D. Efektivitas Model Inkuiri Berbantuan Modul dalam meningkatkan Pemahaman Konsep dan Keterampilan Generik Sains. J Inov Pendidik Kim 2014;8(1):1340-50.

7. Kemendikbud. Buku Pegangan Pembelajaran Berorientasi Pada Keterampilan Berpikir Tingkat tinggi. Jakarta: Direktorat Jenderal Guru dan Tenaga Kependidikan; 2018.

8. Kemendikbud. Modul Penyusunan Soal Higher Order Thinking Skills (HOTS). Jakarta: Direktorat Pembinaan SMA; 2017.

9. Iryani, Mawardi and A. Pengaruh Penggunaan LKS Berbasis Inkuiri Terbimbing Terhadap Hasil Belajar Siswa Untuk Materi Koloid Kelas XI SMAN 1 Batusangkar. Eksakta 2016;1.

10. Mainali BP. Higher Order Thinking in Education. Acad Voices A Multidiscilinary I 2012;2(1):5-10.

11. Plomp T. Educational Design Research: An Introduction", dalam An Introduction to Educational Research. Enschede, Netherland: National Institute for Curriculum Development; 2007.

12. Boslaugh S dan PAW. Statistics in a Nutshell, a desktop quick reference. Beijing, Cambridge, Famham, Köln, Sebastopol, Taipei,Tokyo: O'reilly;

13. Departemen Pendidikan Nasional. Panduan Pengembangan Bahan Ajar. Jakarta: Departemen Pendidikan Nasional, Direktorat Jenderal Manajemen Pendidikan Dasar dan Menengah, Direktorat Pembinaan Sekolah Menengah Atas; 2008.

14. Majid A. Panduan Kreatif Membuat Bahan Ajar Inovatif. Yogyakarta: Diva Press; 2011.

15. Prastowo A. Panduan Kreatif Membuat Bahan Ajar Inovatif. Yogyakarta: Diva Press; 2011. 